\title{
Synthetic Applications and Mechanistic Studies of the Hydroxide-Mediated Cleavage of Carbon-Carbon Bonds in Ketones
}

\author{
Mazziotta, Andrea; Makarov, llya S.; Fristrup, Peter; Madsen, Robert
}

Published in:

Journal of organic chemistry

Link to article, DOI:

10.1021/acs.joc.7b00802

Publication date:

2017

Document Version

Peer reviewed version

Link back to DTU Orbit

Citation (APA):

Mazziotta, A., Makarov, I. S., Fristrup, P., \& Madsen, R. (2017). Synthetic Applications and Mechanistic Studies of the Hydroxide-Mediated Cleavage of Carbon-Carbon Bonds in Ketones. Journal of organic chemistry, 82(11), 5890-5897. https://doi.org/10.1021/acs.joc.7b00802

\section{General rights}

Copyright and moral rights for the publications made accessible in the public portal are retained by the authors and/or other copyright owners and it is a condition of accessing publications that users recognise and abide by the legal requirements associated with these rights.

- Users may download and print one copy of any publication from the public portal for the purpose of private study or research.

- You may not further distribute the material or use it for any profit-making activity or commercial gain

- You may freely distribute the URL identifying the publication in the public portal 


\title{
Synthetic Applications and Mechanistic Studies of the Hydroxide-Mediated
}

\section{Cleavage of Carbon-Carbon Bonds in Ketones}

\author{
Andrea Mazziotta, ${ }^{\dagger}$ Ilya S. Makarov,${ }^{\dagger}$ Peter Fristrup ${ }^{\dagger}$ and Robert Madsen ${ }^{*}, \dagger$ \\ †Department of Chemistry, Technical University of Denmark, 2800 Kgs. Lyngby, Denmark \\ *Department of Chemistry, Ludwig-Maximilians-Universität, Butenandtstr. 5-13, 81377 Munich, Germany
}

E-mail: rm@kemi.dtu.dk

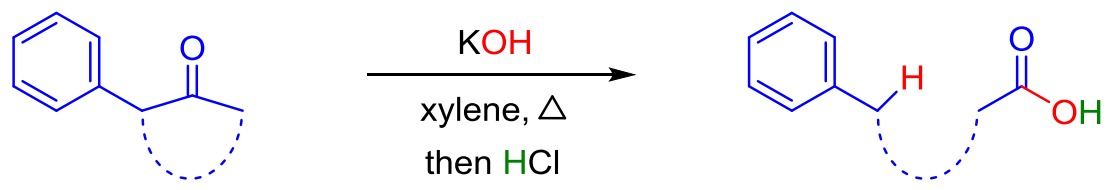

\begin{abstract}
The hydroxide-mediated cleavage of ketones into alkanes and carboxylic acids has been reinvestigated and the substrate scope extended to benzyl carbonyl compounds. The transformation is performed with a $0.05 \mathrm{M}$ ketone solution in refluxing xylene in the presence of 10 equiv. of potassium hydroxide. The reaction constitutes a straightforward protocol for the synthesis of certain phenyl-substituted carboxylic acids from 2-phenylcycloalkanones. The mechanism was investigated by kinetic experiments which indicated a first order reaction in hydroxide and a full negative charge in the rate-determining step. The studies were complemented by a theoretical investigation where two possible pathways were characterized by DFT/M06-2X. The calculations showed that the scission takes place by nucleophilic attack of
\end{abstract}


hydroxide on the ketone followed by fragmentation of the resulting oxyanion into the carboxylic acid and a benzyl anion.

\section{INTRODUCTION}

The cleavage of carbon-carbon bonds in aldehydes and ketones by hydroxide has been known for more than a century. ${ }^{1}$ The most prominent example is the haloform reaction where a trihalomethyl anion is released from the carbonyl compound..$^{2}$ In this case, the reaction occurs readily due to the relatively low $\mathrm{p} K_{\mathrm{a}}$ of the corresponding acid $\left(\mathrm{p} K_{\mathrm{a}}\right.$ for $\left.\mathrm{CHX}_{3}=18-21\right){ }^{3}$ However, the transformation is not limited to relatively acidic carbon moieties and a variety of anions have been cleaved from aldehydes and ketones in hydroxide solution. This includes the anions of methyl ketones, ${ }^{4}$ acetylenes,${ }^{5}$ triphenylmethanes, ${ }^{6} 2,6$-dihalobenzenes, ${ }^{7}$ cumenes ${ }^{8}$ and benzenes ${ }^{9}$ where the $\mathrm{p} K_{\mathrm{a}}$ values of the acids varies between 20 and 43 . The rate of the reactions correlates very well with the stability of the released carbanions. ${ }^{1}$ The scissions are either

performed in aqueous hydroxide solution, ${ }^{4,5,7}$ with potassium hydroxide in an inert solvent ${ }^{6,9 a}$ or with a special mixture of water (3 equiv.) and potassium tert-butoxide (10 equiv.) in an ether solvent. ${ }^{8,9 b, c}$

The mechanism of the cleavage reaction has been investigated by kinetic measurements in aqueous solution where two general pathways have been identified (Scheme 1). ${ }^{2,4,5,7}$ After addition of hydroxide the resulting oxyanion 1 can either decompose to the products or undergo a second reaction with hydroxide to form dioxyanion $\mathbf{2}$. The latter decomposes rapidly to the products and this dioxyanion route has been determined as the main reaction pathway in water. The direct decomposition of oxyanion $\mathbf{1}$ has only been detected experimentally when rather 
stable carbanions are released such as the anion of chloroform, methyl ketones and phenylacetylene. ${ }^{2,4,5}$ It is, however, not a trivial task to distinguish between the two pathways and the kinetic profile can in both cases be described as pseudo first order in hydroxide when the base is used in excess. ${ }^{10}$ Except for the haloform reaction, the transformation has so far only gained moderate attention in synthesis. ${ }^{11,12}$ This is mainly due to the narrow substrate scope and the occurrence of competing reactions such as the Cannizzaro reaction for benzaldehydes and the aldol reaction for enolizable carbonyl compounds. A variation of the reaction involves formation of carboxamides by cleavage of ketones with alkali metal amides. ${ }^{11,13}$ This transformation was originally termed the Haller-Bauer reaction, ${ }^{14}$ but the name is today often used to describe the splitting with both amide and hydroxide ions.

\section{Scheme 1. Two Mechanistic Pathways for Hydroxide-Mediated Cleavage}

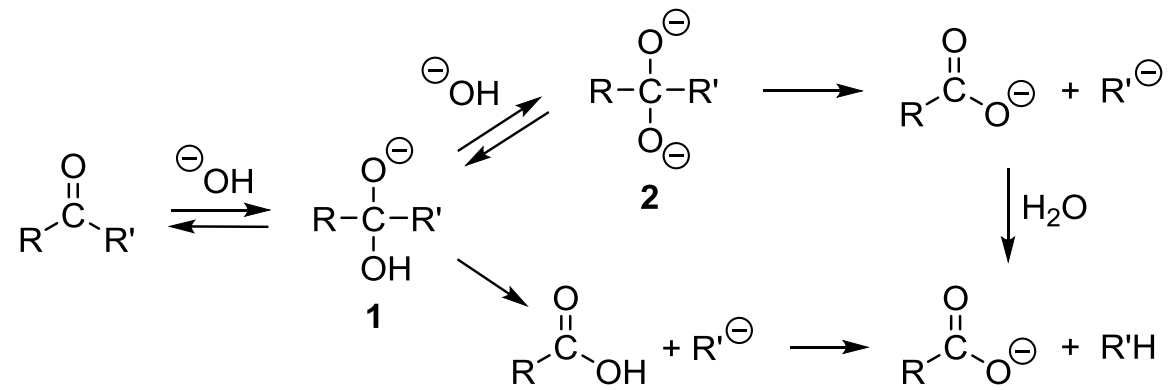

Toluene has a $\mathrm{p} K_{\mathrm{a}}$ of 41 and the anion should be able to serve as a departing group in the cleavage reaction which would broaden the substrate scope of this very simple transformation. In addition, it would be interesting to further investigate the mechanism by modern computational methods which may provide a more clear distinction between the two reaction pathways. Therefore, we herein describe the hydroxide-mediated cleavage of benzyl carbonyl 
compounds and experimental investigations of the mechanism complemented by a density functional theory study.

\section{RESULTS AND DISCUSSION}

The reaction was discovered during our work on the oxidation of primary alcohols into carboxylic acids with the liberation of molecular hydrogen. ${ }^{15}$ This transformation is catalyzed by the ruthenium complex $\left[\mathrm{RuCl}_{2} \mathrm{I} i \mathrm{Pr}(p\right.$-cymene $\left.)\right](\mathrm{I} i \mathrm{Pr}=1,3$-diisopropylimidazol-2-ylidene $)$ and proceeds by dehydrogenation to the aldehyde followed by addition of hydroxide ion and dehydrogenation to the acid. The optimized conditions employ $1 \%$ of $\left[\operatorname{RuCl}_{2} \mathrm{I} i \operatorname{Pr}(p\right.$-cymene $\left.)\right]$, $1 \%$ of $\mathrm{PCy}_{3} \cdot \mathrm{HBF}_{4}$, and a slight excess of potassium hydroxide in refluxing toluene. ${ }^{15}$ In this way, the potassium salt of phenylacetic acid was obtained by dehydrogenation of 2-

phenylethanol which after workup with hydrochloric acid gave the carboxylic acid (Scheme 2). ${ }^{15}$ However, it was never possible to isolate the acid in more than $75 \%$ yield. The byproduct became evident when the solvent was replaced with refluxing xylene which now gave a 76\% GC yield of toluene. Apparently, the hydroxymethyl group is cleaved from the starting alcohol and NMR analysis of the heterogeneous mixture revealed that potassium formate was also formed. No fragmentation occurred when 2-phenylethanol or 2-phenylacetic acid were heated with $\mathrm{KOH}$ in the absence of the ruthenium catalyst.

\section{Scheme 2. Oxidation and Cleavage of 2-Phenylethanol}




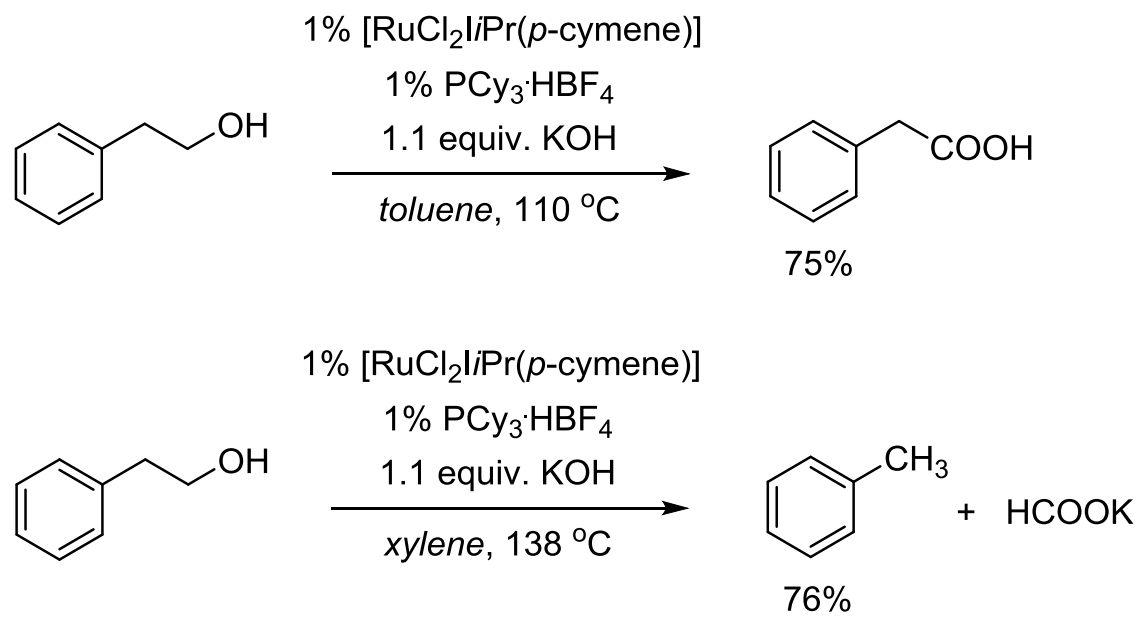

These observations made us consider the reaction in Scheme 1 as a possible explanation for the cleavage. Supposedly, the ruthenium catalyst dehydrogenates 2-phenylethanol to the aldehyde which is formed in amounts too low for an aldol condensation to occur. Instead, attack of hydroxide takes place to furnish toluene and formate. ${ }^{16}$ This was confirmed by the addition of 2-phenylacetaldehyde by syringe pump over $2 \mathrm{~h}$ to a refluxing mixture of $\mathrm{KOH}$ (10 equiv.) in xylene which gave toluene in $89 \%$ yield as determined by GC (Table 1, entry 1). On the contrary, only $11 \%$ of toluene was obtained when a $0.5 \mathrm{M}$ solution of 2-phenylacetaldehyde in xylene was heated with $\mathrm{KOH}$ (entry 2). These results clearly illustrate the importance of a low concentration of the aldehyde in order to achieve the carbon-carbon cleavage product in good yield. Notably, when the reaction was diluted 10-fold and performed with a $0.05 \mathrm{M}$ solution of 2-phenylacetaldehyde, the yield of toluene increased to $85 \%$ (entry 3 ). This is almost the same result as obtained by slow addition of the aldehyde, but using more convenient reaction conditions. When the base was replaced by $\mathrm{NaOH}$ under the same conditions the yield dropped to $20 \%$ (entry 4). The yield also decreased with lower amounts of $\mathrm{KOH}$ where the competing aldol condensation occurred to a larger extend. No cleavage took place when lowering the 
temperature to $80^{\circ} \mathrm{C}$ or by changing the solvent to refluxing water or DMSO which in all cases led to poor conversion and several side-products. Thus, the optimized conditions for the fragmentation involve reflux of a $0.05 \mathrm{M}$ solution of the carbonyl compound in xylene with 10 equiv. of $\mathrm{KOH}$.

Table 1. Cleavage of 2-Phenylacetaldehyde

\begin{tabular}{lcc}
\hline & $\prod_{\mathrm{O}}$ & $\frac{10 \text { equiv. } \mathrm{KOH}}{\text { xylene, } 138^{\circ} \mathrm{C}}$ \\
\hline entry & {$\left[\mathrm{PhCH}_{2} \mathrm{CHO}\right](\mathrm{M})$} & yield $(\%)^{a}$ \\
\hline $1^{b}$ & 0.5 & 89 \\
2 & 0.5 & 11 \\
$\mathbf{3}$ & $\mathbf{0 . 0 5}$ & $\mathbf{8 5}$ \\
$4^{c}$ & 0.05 & 20 \\
\hline
\end{tabular}

${ }^{a} \mathrm{GC}$ yield. ${ }^{b} \mathrm{PhCH}_{2} \mathrm{CHO}$ added over 2 h. ${ }^{c} \mathrm{NaOH}$ used instead of $\mathrm{KOH}$.

With these conditions in hand a number of carbonyl compounds with benzyl moieties were subjected to the cleavage reaction in order to investigate the substrate scope and limitations (Table 2). The scission proceeded smoothly with phenylacetone where toluene was obtained in $91 \%$ yield (entry 1 ). Diphenylacetaldehyde, on the other hand, gave diphenylmethane in only $21 \%$ yield together with several high molecular products which were not further identified (entry 2). The fragmentation was also amenable to cyclic ketones where useful procedures for preparation of several carboxylic acids could be obtained. The cleavage of 2phenylcyclohexanone gave 6-phenylhexanoic acid in 78\% isolated yield (entry 3). A slightly lower yield was achieved when an additional 2-substituent was present in the cyclohexanone 
which is presumably due to the increased steric hindrance (entries 4-6). Essentially no cleavage was observed with the parent cyclohexanone which illustrates the importance of the stabilization from the 2-phenyl substituent (result not shown). The fragmentation of $\beta$-tetralone was completely regioselective although the product was only produced in a low yield (entry 7). Fivemembered ketones could also undergo the cleavage as shown with 2-phenylpentanone and 2indanone which afforded the carboxylic acids in 64 and 90\% yield, respectively (entries 8 and 9). 2,2,5,5-Tetramethylcyclopentanone, on the contrary, did not react which confirms the importance of the benzyl moiety for the scission to occur.

Table 2. Hydroxide-Mediated Cleavage of Carbonyl Compounds ${ }^{a}$

entry substrate


6<smiles>O=C1CCCCC1(Cc1ccccc1)c1ccccc1</smiles>

7<smiles>O=C1CCc2ccccc2C1</smiles>

8<smiles>O=C1CCCC1c1ccccc1</smiles>

9<smiles>O=C1Cc2ccccc2C1</smiles><smiles>O=C(O)CCCCC(Cc1ccccc1)c1ccccc1</smiles><smiles>Cc1ccccc1CCC(=O)O</smiles><smiles>O=C(O)CCCCc1ccccc1</smiles><smiles>Cc1ccccc1CC(=O)O</smiles>

76

18

64

90

${ }^{a}$ Conditions: Carbonyl compound $(2.5 \mathrm{mmol})$ and $\mathrm{KOH}(25 \mathrm{mmol})$ in refluxing xylene for $1 \mathrm{~h} .{ }^{b}$ Isolated yield. ${ }^{c} \mathrm{GC}$ yield.

In addition to the synthetic utility we were also interested in a further clarification of the reaction mechanism especially the differences and the analogies to the already established pathways. We started with a kinetic analysis where phenylacetone was selected as the substrate since it gave the highest yield in Table 2. As displayed in Scheme 1 two main pathways have been identified for the cleavage of carbonyl compounds. When the oxyanion $\mathbf{1}$ is formed, the nature of the leaving group $\mathrm{R}^{\prime}$ determines the subsequent reaction where stabilized residues may be expelled directly while strongly basic moieties require a larger activation energy giving rise to the extremely reactive dioxyanion 2 . The latter can only be formed with bases containing extractable hydrogen such as the hydroxide and the amide anions. This was confirmed by treating phenylacetone with stoichiometric amounts of sodium methoxide and potassium tertbutoxide which in both cases only led to poor conversion and small amounts of toluene (14\% and 5\%, respectively). On the other hand, the addition of 3 equiv. of water to the reaction with 
potassium tert-butoxide increased the yield to $77 \%$ which supports the fact that hydroxide ions are responsible for the cleavage.

The reaction order with respect to the base was also determined for phenylacetone (Figure 1). A linear dependence was observed, but only until a $\left[\mathrm{OH}^{-}\right]$of around $0.4 \mathrm{M}$ after which a minor decrease in the rate of cleavage was detected. This may illustrate the point of saturation since the base is not fully soluble under these conditions. ${ }^{17}$ The initial linear relationship suggests that the reaction is first order in hydroxide.

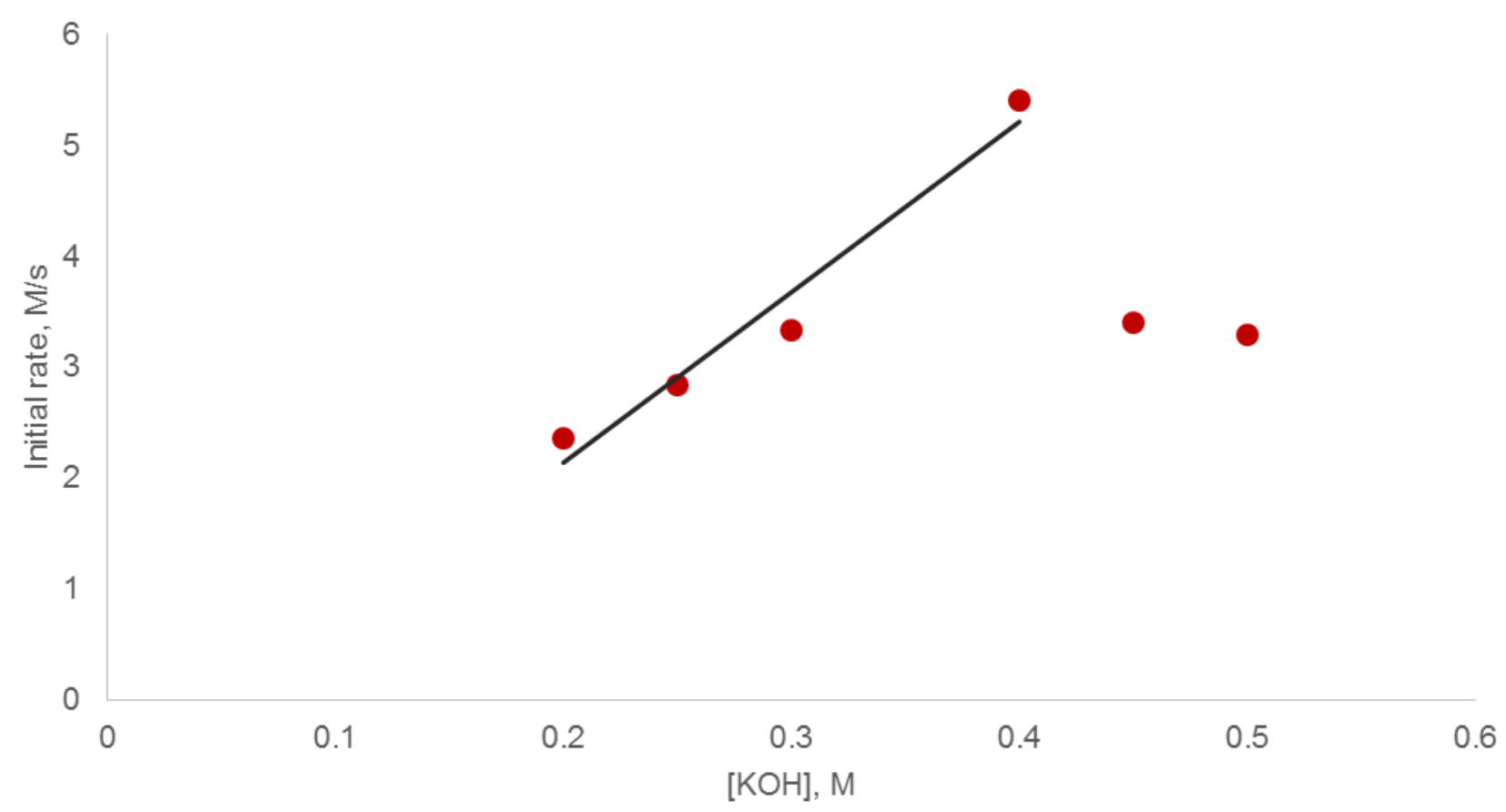

Figure 1. Dependence between the rate of cleavage and the amount of the base

In an attempt to locate the rate-determining step, a Hammett study was carried out with different para-substituted aryl acetones. The reactions were conducted as competition experiments in which the parent phenylacetone was allowed to compete with the other parasubstituted aryl acetones in the presence of potassium hydroxide (Scheme 3). ${ }^{18}$ The formation of 
the different toluene derivatives was quantified by GC as a function of the reaction time and the results are displayed in Figure 2 and Table $3 .^{19}$

Scheme 3. Substrates for Hammett study
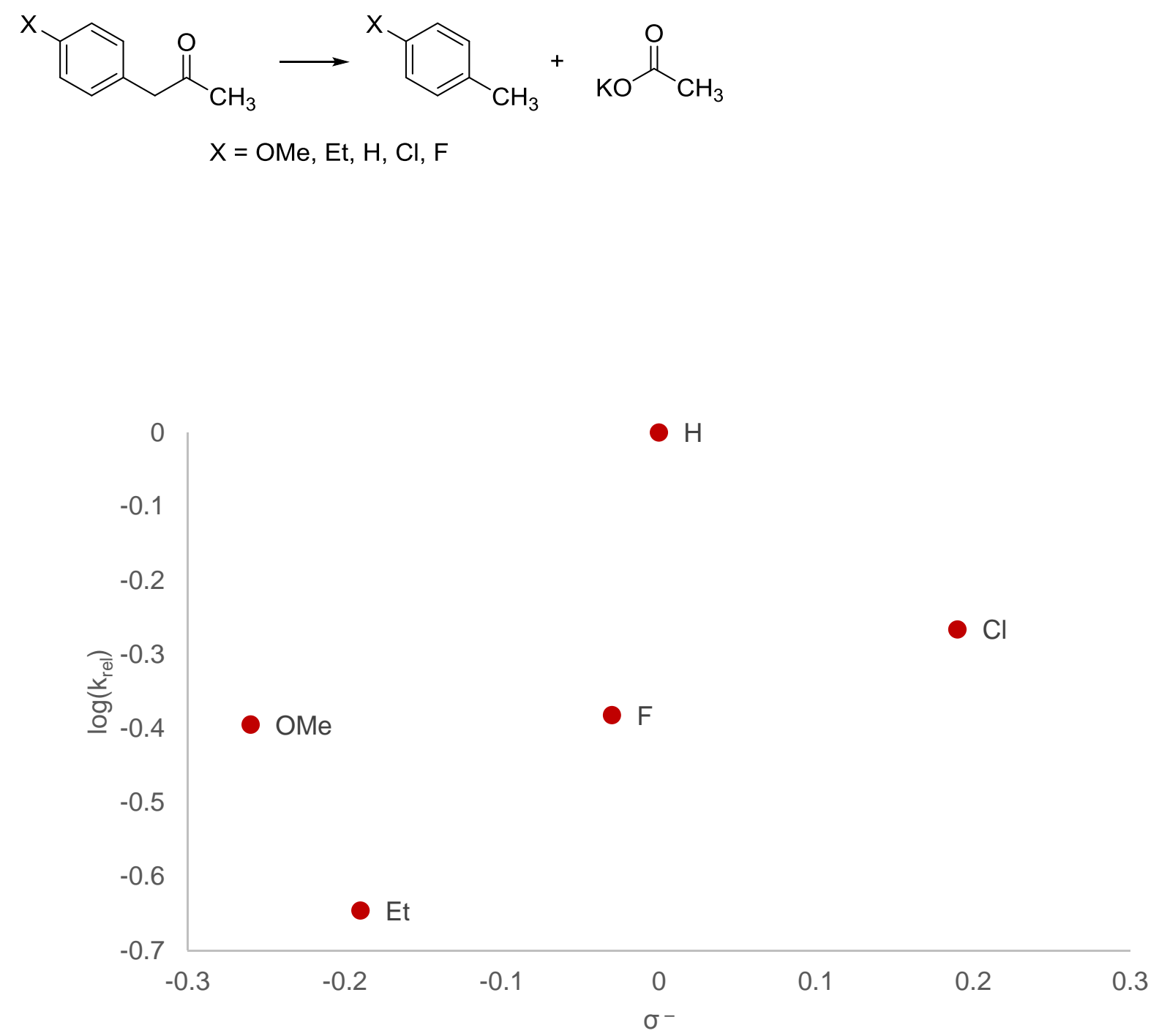

Figure 2. Distribution of relative reactivities in Hammett experiment 


\section{Table 3. Data from Hammett Experiment}

\begin{tabular}{ccccc}
\hline $\mathrm{X}$ & $\mathrm{p} K_{\mathrm{a}}{ }^{*}$ & $\sigma^{-}$ & $\log \left(\mathrm{k}_{\mathrm{rel}}\right)$ & $\begin{array}{c}\log \left(\mathrm{k}_{\mathrm{rel}}\right)- \\
\mathrm{p} K_{\mathrm{a}}^{\mathrm{X}}+\mathrm{p} K_{\mathrm{a}}^{\mathrm{H}}\end{array}$ \\
\hline $\mathrm{OMe}$ & 22.5 & -0.26 & -0.395 & -2.195 \\
$\mathrm{Et}$ & 21.5 & -0.19 & -0.646 & -1.446 \\
$\mathrm{H}$ & 20.7 & 0 & 0 & 0 \\
$\mathrm{~F}$ & 20.7 & -0.03 & -0.382 & -0.382 \\
$\mathrm{Cl}$ & 19.6 & 0.19 & -0.266 & 0.834 \\
\hline
\end{tabular}

${ }^{*} p K_{a}$ in DMSO calculated: Jaguar, version 7.8. Schrodinger, LLC, New York, NY, 2010

Clearly, no linear correlation was observed which is most likely due to the dual reactivity of the ketones since the base can mediate both the cleavage reaction and a deprotonation. These two factors can be isolated by determining the acid dissociation constant by DFT calculations for the aryl acetones. The $\mathrm{p} K_{\mathrm{a}}$ values in DMSO for the structures minimized in xylene are also displayed in Table 3. The dissociation constants for both the non-substituted and the substituted ketone are used to correct the relative reactivities from the competition experiments according to eq. $1 .^{20}$

$$
\log \left(\mathrm{k}_{\text {rel }}\right)-\mathrm{p} K_{\mathrm{a}}^{\mathrm{X}}+\mathrm{p} K_{\mathrm{a}}^{\mathrm{H}}=\sigma^{-} \rho
$$

The corrected values are also listed in Table 3 and from the new plot in Figure 3 a straight line is now obtained with a slope of approximately 6.7 which shows that almost a full negative charge is developed in the rate-determining step. 


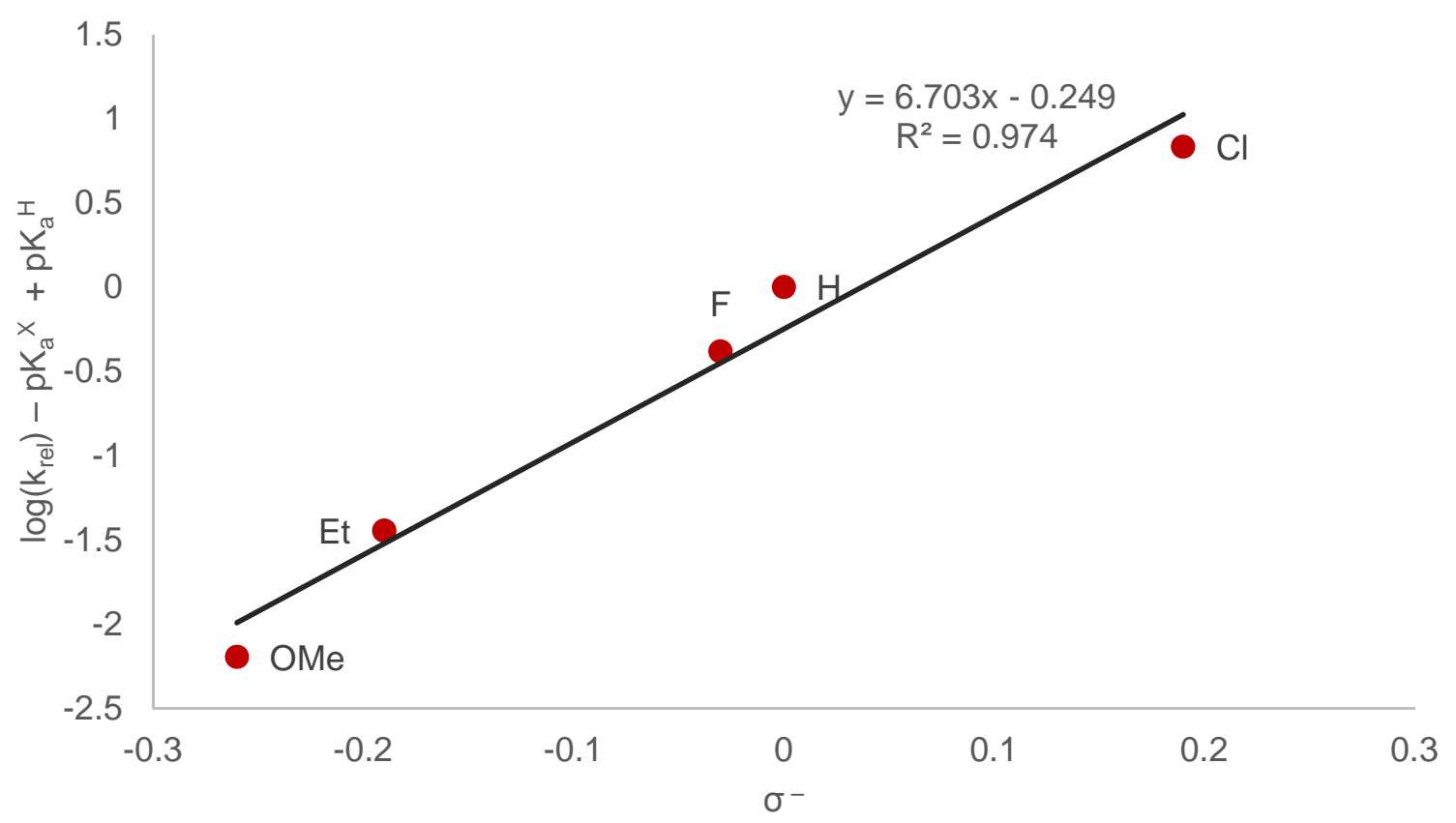

Figure 3. Hammett plot modulated with the dissociation constants $K_{\mathrm{a}}$

To increase our understanding of the reaction pathways the investigation was extended with a computational study which has not been performed before for this cleavage reaction. ${ }^{21} 2,6-$ Dichlorobenzaldehyde $\mathbf{3}$ was selected as a reference substrate since the mechanism for the cleavage of this compound has previously been studied in detail by kinetic measurements in aqueous solution and all the necessary activation parameters were established (Scheme 4). ${ }^{7 \mathrm{~b}}$ Moreover, molecule $\mathbf{3}$ is relatively small and does not have many conformational degrees of freedom, which should facilitate the optimization and the search for the transition states. Finally, 3 as well as 2-phenylacetaldehyde do not contain any heavy atoms and therefore the same basis 
sets can be used in both cases. It was shown experimentally that the cleavage occurs via the dioxyanion 5 with the deformylation of this dioxyanion as the rate-determining step. ${ }^{7 \mathrm{~b}}$ The following activation parameters were measured at $58.4^{\circ} \mathrm{C}: \Delta \mathrm{H}^{\ddagger}=121.2 \mathrm{~kJ} \cdot \mathrm{mol}^{-1}$ and $\Delta \mathrm{S}^{\neq}=$ $37.6 \mathrm{~J} \cdot \mathrm{mol}^{-1} \cdot \mathrm{K}^{-1}$ from which the activation Gibbs free energy can be calculated as $\Delta \mathrm{G}^{\neq}=\Delta \mathrm{H}^{\ddagger}-$ $\mathrm{T} \Delta \mathrm{S}^{\neq}=108.8 \mathrm{~kJ} \cdot \mathrm{mol}^{-1} .^{7 \mathrm{~b}}$ This value was used as a reference for selecting the proper computational method.

\section{Scheme 4. Pathway for Cleavage of 2,6-Dichlorobenzaldehyde}

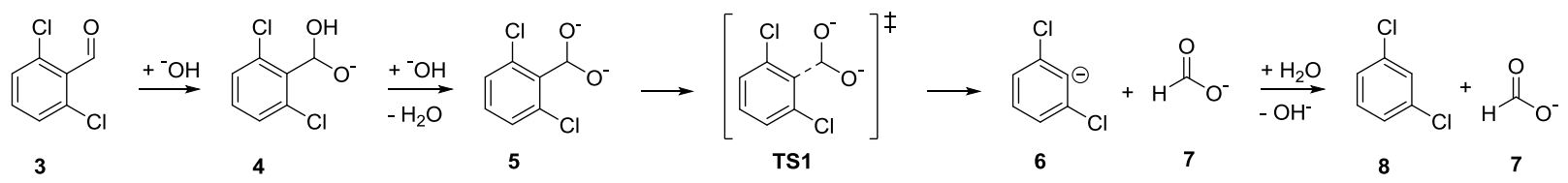

The initial calculations were performed by using the B3LYP-D3 functional and the 6-31G* basis set. However, it was quickly discovered that this level of theory was insufficient as optimization of some of the charged molecules either in gas phase or in solution (without adding explicit solvent molecules) did not converge. Even with a different functional (M06-2X) or larger basis sets it was impossible to locate molecule $\mathbf{5}$ on the potential energy surface and all attempts to optimize it led to the two separate species $\mathbf{6}$ and 7. As a possible solution it was decided to add explicit water molecules around the oxygen atoms to better distribute the negative charge and thus stabilize the intermediate $\mathbf{5}$. It has previously been shown that addition of three water molecules around an oxygen anion could greatly improve the precision of the calculated energy for the reactions involving this anion. ${ }^{22}$ The same approach was employed in 
our recent work on the dehydrogenation of alcohols to carboxylic acids in the presence of hydroxide. ${ }^{15}$

Indeed, adding explicit water molecules stabilized intermediate $\mathbf{5}$ when optimizing its structure at the B3LYP-D3/6-31+G* level of theory. Three water molecules around each oxygen anion formed a small hydrogen-bonded cluster with an average intermolecular $\mathrm{O} \cdots \mathrm{H}$ bond distance of $2.180 \AA$ for the two clusters and an average $\mathrm{O} \cdots \mathrm{H}$ bond distance of $1.836 \AA$ between the negatively charged oxygen atoms of $\mathbf{5}$ and the hydrogen atoms of the water molecules. For consistency three water molecules were similarly added to the other oxygen anions apart from formate anion 7. Moreover, to take into account hydrogen bonding, a water molecule was also optimized with three added water molecules. For all further calculations the water coordinated species in Figure 4 were used instead of the structures in Scheme 4.

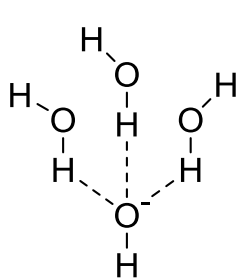

$\mathrm{OH}^{-} \cdot 3 \mathrm{H}_{2} \mathrm{O}$<smiles>OCC(O)[O+](CO)C(O)c1c(Cl)cccc1Cl</smiles>

$4 \cdot 3 \mathrm{H}_{2} \mathrm{O}$<smiles>OCOCO</smiles>

$\left(\mathrm{H}_{2} \mathrm{O}\right)_{4}$

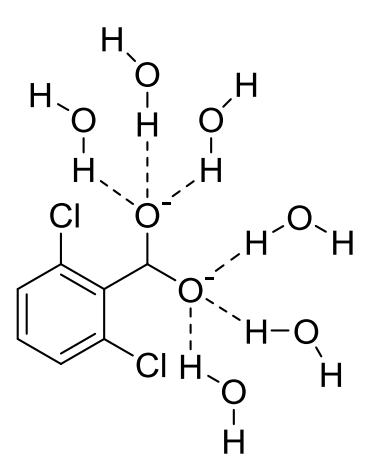

$5 \cdot 6 \mathrm{H}_{2} \mathrm{O}$

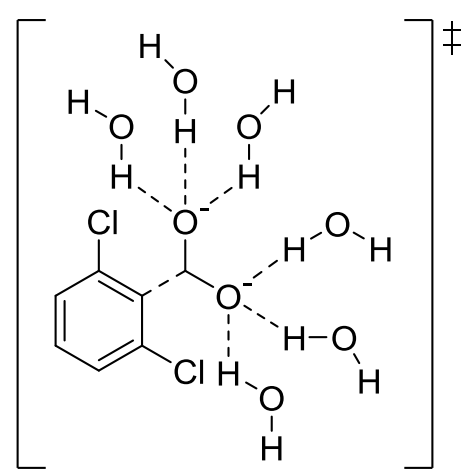

$\mathrm{TS} 1 \cdot 6 \mathrm{H}_{2} \mathrm{O}$

Figure 4. Species with explicit water molecules used in the calculations 
According to the previous experimental studies the cleavage the $\mathrm{C}-\mathrm{C}$ bond in

2,6-dichlorobenzaldehyde proceeds through the formation of dianion $\mathbf{5}$ with its fragmentation as the rate-determining step. For this reason, the finding of transition state TS1 is crucial for the study. Unfortunately, all attempts to locate transition state TS1· $6 \mathrm{H}_{2} \mathrm{O}$ at the B3LYP-D3/6$31+\mathrm{G}^{*}$ level of theory were unsuccessful which made it impossible to use the calculated energies for comparison with the experimental values. Larger basis sets were tried instead, and it was found that only with the $6-31++\mathrm{G}^{* *}$ basis set and the M06-2X functional was it possible to locate all species. After a brief screening of the basis sets it was found that an acceptable difference between the calculated and the measured Gibbs free energy of activation could be obtained when optimizing the species with the $6-311++\mathrm{G}^{* *}$ basis set in water (Table 4$)$.

Table 4. Gibbs Free Energy of Activation Calculated with Different Basis Sets ${ }^{a}$

\begin{tabular}{|l|l|l|l|}
\hline Entry & Basis set & $\Delta G_{a}, \mathrm{~kJ} \cdot \mathrm{mol}^{-1}$ & $\Delta \Delta G_{a}{ }^{\mathrm{b}} \mathrm{kJ}^{-} \mathrm{mol}^{-1}$ \\
\hline 1 & $6-31++\mathrm{G}^{* *}$ & 150.0 & 41.2 \\
\hline 2 & $6-311++\mathrm{G}^{* *}$ & 139.3 & 30.5 \\
\hline $3^{\mathrm{c}}$ & $6-311++\mathrm{G}^{* *}$ & 113.7 & $\mathbf{4 . 9}$ \\
\hline 4 & cc-pVDZ-PP & 140.1 & 31.3 \\
\hline${ }^{a}$ Optimized using M06-2X functional and Gibbs free energy calculated \\
at $58^{\circ} \mathrm{C} .{ }^{b}$ Difference between the calculated and experimental values. ${ }^{c}$ \\
Geometry optimized in water
\end{tabular}

The complete energy profile for the cleavage of 2,6-dichlorobenzaldehyde is shown in Figure 5. The overall transformation is exergonic by $178.9 \mathrm{~kJ} \cdot \mathrm{mol}^{-1}$. In the first step, aldehyde $\mathbf{3}$ is attacked by a hydroxide ion (i.e. $\mathrm{OH}^{-} \cdot 3 \mathrm{H}_{2} \mathrm{O}$ ) to give intermediate $4 \cdot 3 \mathrm{H}_{2} \mathrm{O}$ which resulted in an energy decrease of $15 \mathrm{~kJ} \cdot \mathrm{mol}^{-1}$. The deprotonation of this species leads to the formation of a key intermediate - dioxyanion $5 \cdot 6 \mathrm{H}_{2} \mathrm{O}$ which undergoes deformylation through the transition state TS1 $6 \mathrm{H}_{2} \mathrm{O}$. The Gibbs free energy for this step is $113.7 \mathrm{~kJ} \cdot \mathrm{mol}^{-1}$ which is only $4.9 \mathrm{~kJ} \cdot \mathrm{mol}^{-1}$ 
higher than the experimental value. The resulting dichlorophenyl anion $\mathbf{6}$ abstracts a proton from a water molecule resulting in a further energy decrease of almost $90 \mathrm{~kJ} \cdot \mathrm{mol}^{-1}$. Thus, the selected combination of the $6-311++\mathrm{G}^{* *}$ basis set and the M06-2X functional made it possible to obtain activation parameters for the cleavage of 2,6-dichlorobenzaldehyde that are very close to the experimental values.

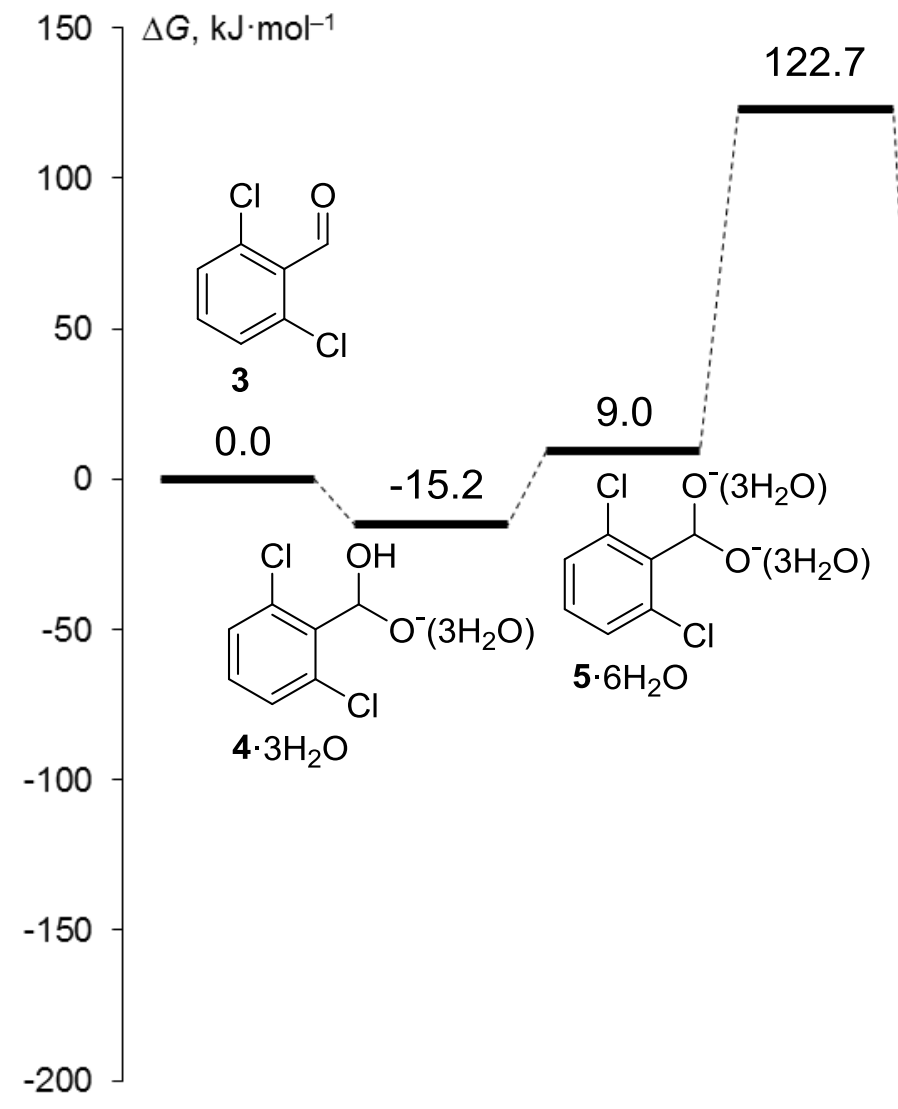

Figure 5. Energy profile for the cleavage of 2,6-dichlorobenzaldehyde

With this method available, the computational study could now be extended to 2phenylacetaldehyde in order to determine which of the two cleavage pathways are applicable in this case. 2-Phenylacetaldehyde was selected as the substrate for the calculations since the 
cleavage reaction was originally discovered with this molecule. Although, water is not explicitly added to the reaction, solid $\mathrm{KOH}$ contains $0.35-0.55$ equiv. of $\mathrm{H}_{2} \mathrm{O}$ per equiv. of hydroxide depending on the quality of the base and $\mathrm{KOH}$ is used in excess in this transformation. The two pathways are illustrated in Scheme 5 with the formation of the dioxyanion as pathway A and the direct fragmentation of the monooxy anion as pathway B. The energy profiles for both pathways are shown in Figure 6. It can be seen that pathway B is more favorable than pathway A by almost $100 \mathrm{~kJ} \cdot \mathrm{mol}^{-1}$ starting from the common intermediate $\mathbf{1 0 a} \cdot 3 \mathrm{H}_{2} \mathrm{O}$. Even though the barrier for the fragmentation step is lower for pathway $\mathrm{A}\left(\Delta G^{\neq}(\mathrm{A})=40.5 \mathrm{~kJ} \cdot \mathrm{mol}^{-1}, \Delta G^{\ddagger}(\mathrm{B})=117.1\right.$ $\mathrm{kJ} \cdot \mathrm{mol}^{-1}$ ), the preceding deprotonation step leads to a high lying dianion $\mathbf{1 0 b} \cdot 6 \mathrm{H}_{2} \mathrm{O}$ $\left(\Delta G\left(\mathbf{1 0 b} \cdot 6 \mathrm{H}_{2} \mathrm{O}\right)-\Delta G\left(\mathbf{1 0 a} \cdot 3 \mathrm{H}_{2} \mathrm{O}\right)=173.3 \mathrm{~kJ} \cdot \mathrm{mol}^{-1}\right)$ which renders pathway A less favorable overall. With the monooxy anion pathway as the preferred route, the DFT calculations confirm the results from the Hammett study where a full charge is revealed in the rate-determining step.

Scheme 5. Two Possible Pathways for Cleavage of 2-Phenylacetaldehyde

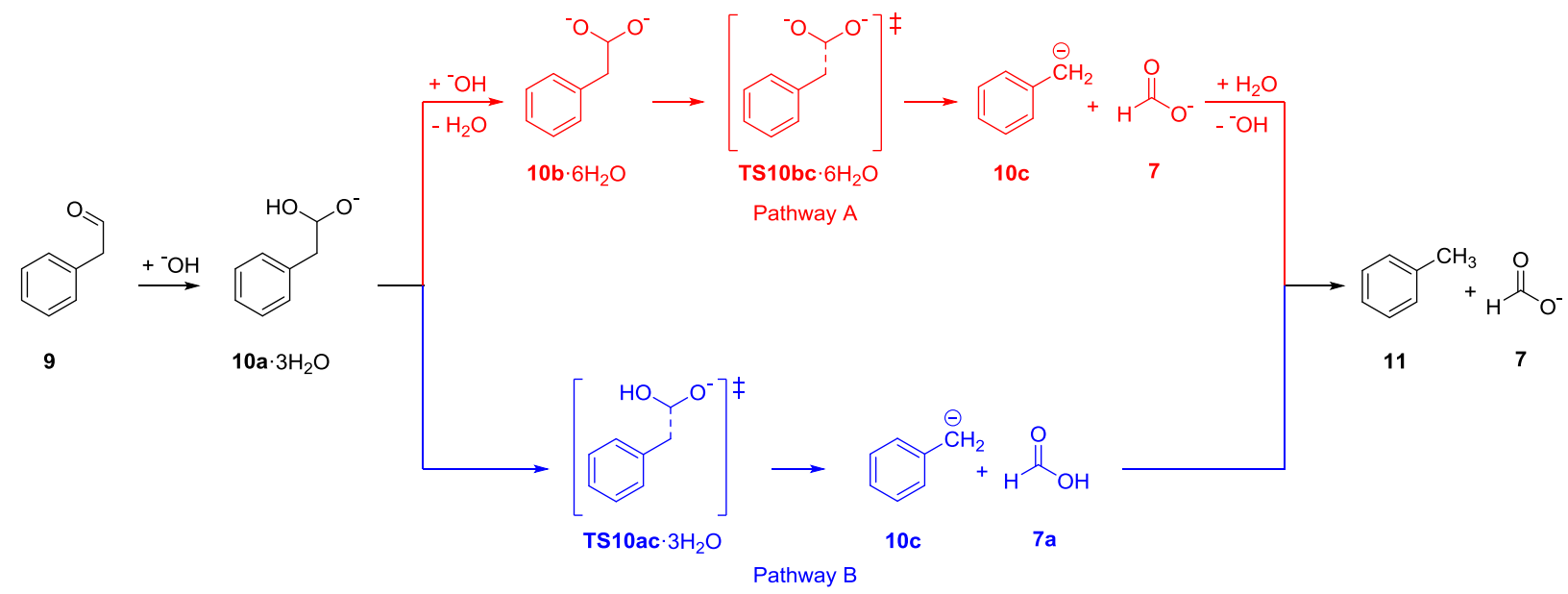


The solvent is most likely responsible for the monooxy anion pathway being favored in this case. The previous kinetic studies on the cleavage of ketones and aldehydes have all been carried out in water where the dianion pathway was shown to be the preferred cleavage route. ${ }^{2,4,7}$ However, xylene is poor at solvating oxygen anions (even with added water molecules) and as a result the dioxyanion becomes more unfavorable in this case and leads to the fragmentation through the monooxy anion.

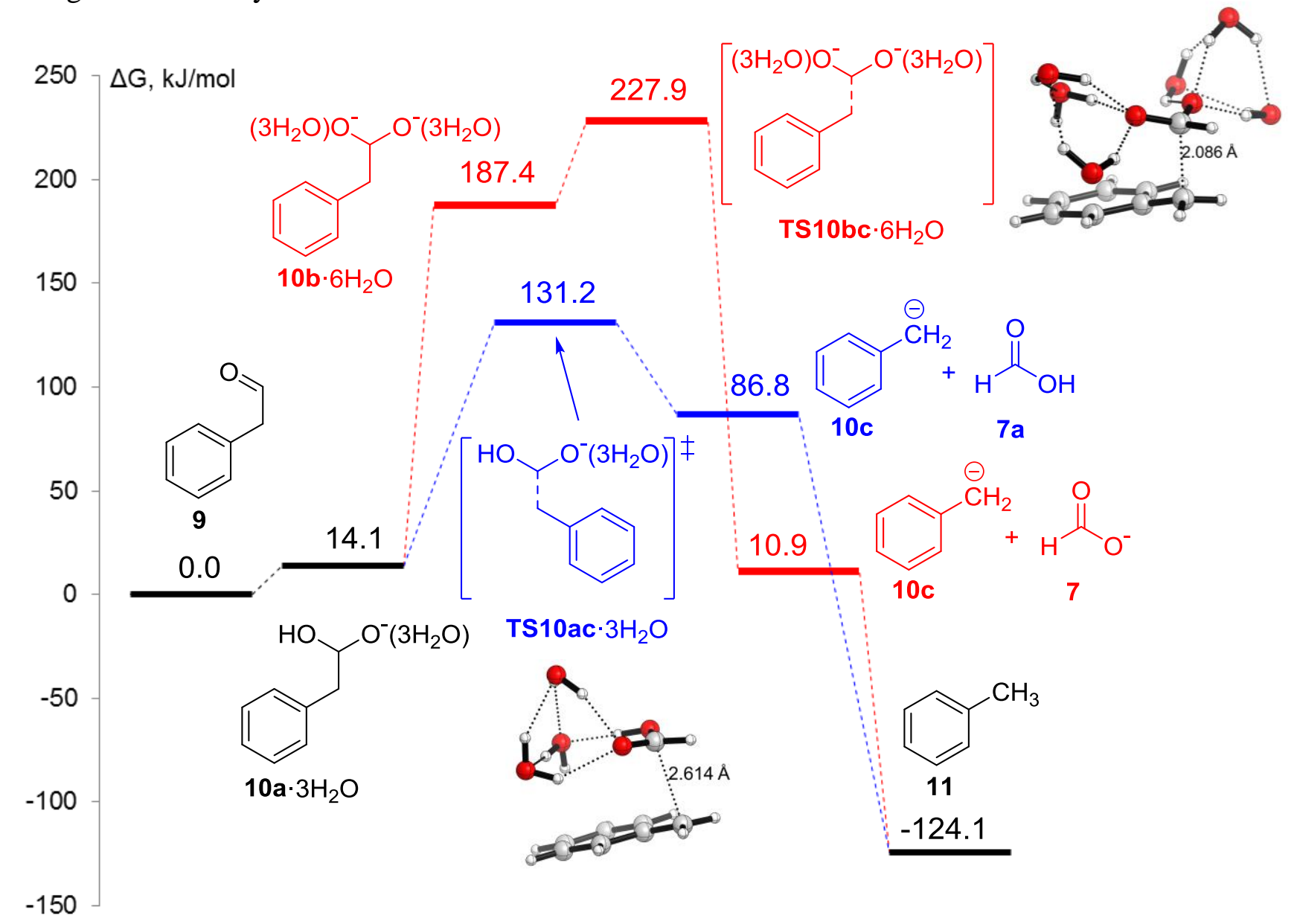

Figure 6. Energy profile for pathways A and B

In conclusion, the substrate scope of the potassium hydroxide-mediated carbon-carbon cleavage reaction was extended to benzyl carbonyl compounds and the mechanism for the reaction was investigated with both experimental and theoretical methods. The reaction was 
found to proceed through a monooxy anion intermediate in xylene solution in contrast to what has previously been reported in the literature for the scission of aldehydes and ketones in aqueous media. The results show that DFT calculations can be employed to distinguish between the two reaction pathways and the good agreement between experiment and theory opens up for the possibility of in silico substrate screening.

\section{EXPERIMENTAL SECTION}

General Information. All solvents were of HPLC grade and were not further purified. Column chromatography separations were performed on silica gel (220 - 440 mesh). NMR chemical shifts were measured relative to the signals of residual $\mathrm{CHCl}_{3}\left(\delta_{\mathrm{H}} 7.26 \mathrm{ppm}\right)$ and $\mathrm{CDCl}_{3}\left(\delta_{\mathrm{C}}\right.$ 77.16 ppm). HRMS measurements were made using ESI with TOF detection. Phenylacetones, ${ }^{23}$ 2-phenylcyclopentanone $e^{24}$ and -cyclohexanone ${ }^{25}$ were prepared according to literature procedures.

2-Methyl-2-phenylcyclohexanone (Table 2, entry 4): ${ }^{26}$ Following a literature procedure ${ }^{26} 2$ phenylcyclohexanone $(1.0 \mathrm{~g}, 5.74 \mathrm{mmol})$ in tert-butanol $(10 \mathrm{~mL})$ was treated with potassium tert-butoxide $(673 \mathrm{mg}, 6.00 \mathrm{mmol})$ for $45 \mathrm{~min}$ followed by addition of methyl iodide $(0.7 \mathrm{~mL}$, $11.2 \mathrm{mmol})$. The mixture was stirred at room temperature for $2.5 \mathrm{~h}$ and worked up by addition of water and extraction with EtOAc. Purification by flash chromatography (heptane/EtOAc 95/5) gave $950 \mathrm{mg}(88 \%)$ of the product as a colorless oil. ${ }^{1} \mathrm{H} \mathrm{NMR}\left(400 \mathrm{MHz}, \mathrm{CDCl}_{3}\right) \delta 7.35(\mathrm{t}, J=$ $7.6 \mathrm{~Hz}, 2 \mathrm{H}), 7.24(\mathrm{t}, J=7.4 \mathrm{~Hz}, 1 \mathrm{H}), 7.20-7.18(\mathrm{~m}, 2 \mathrm{H}), 2.71-2.68(\mathrm{~m}, 1 \mathrm{H}), 2.45-2.25(\mathrm{~m}, 2 \mathrm{H})$, 1.76-1.65 (m, 4H), 2.02-1.92 (m, 1H), $1.27(\mathrm{~s}, 3 \mathrm{H}) .{ }^{13} \mathrm{C} \mathrm{NMR}\left(100 \mathrm{MHz}, \mathrm{CDCl}_{3}\right) \delta 214.3$, $143.4,129.1,126.7,126.2,54.5,40.1,38.3,28.6,28.6,22.0$. 
2-Ethyl-2-phenylcyclohexanone (Table 2, entry 5): ${ }^{27}$ Prepared in $81 \%$ yield $(940 \mathrm{mg})$ as a colorless oil from 2-phenylcyclohexanone and ethyl iodide as described above for 2-methyl-2phenylcyclohexanone. ${ }^{1} \mathrm{H}$ NMR $\left(400 \mathrm{MHz}, \mathrm{CDCl}_{3}\right) \delta 7.34(\mathrm{t}, J=7.6 \mathrm{~Hz}, 2 \mathrm{H}), 7.23(\mathrm{t}, J=7.3$ $\mathrm{Hz}, 1 \mathrm{H}), 7.15(\mathrm{~d}, J=7.3 \mathrm{~Hz}, 2 \mathrm{H}), 2.74-2.70(\mathrm{~m}, 1 \mathrm{H}), 2.40-2.10$ (m, 2H), 1.94 (ddd, $J=2.9,5.9$, $12.0 \mathrm{~Hz}, 1 \mathrm{H}), 1.88-1.59(\mathrm{~m}, 6 \mathrm{H}), 0.61(\mathrm{t}, J=7.5 \mathrm{~Hz}, 3 \mathrm{H}) .{ }^{13} \mathrm{C} \mathrm{NMR}\left(100 \mathrm{MHz}, \mathrm{CDCl}_{3}\right) \delta 214.1$, $140.9,128.8,127.2,126.7,57.7,40.4,34.5,32.6,28.5,21.8,8.2$.

2-Benzyl-2-phenylcyclohexanone (Table 2, entry 6): ${ }^{28}$ Prepared in $90 \%$ yield (1.4 g) as a white solid from 2-phenylcyclohexanone and benzyl bromide as described above for 2-methyl-2phenylcyclohexanone. ${ }^{1} \mathrm{H}$ NMR (400 MHz, $\left.\mathrm{CDCl}_{3}\right) \delta 7.32-7.21(\mathrm{~m}, 3 \mathrm{H}), 7.13-7.02(\mathrm{~m}, 3 \mathrm{H})$, 6.96-6.94 (m, 2H), 6.57-6.54 (m, 2H), $3.12(\mathrm{~d}, J=13.5 \mathrm{~Hz}, 1 \mathrm{H}), 2.98(\mathrm{~d}, J=13.5 \mathrm{~Hz}, 1 \mathrm{H})$, 2.48-2.46 (m, 1H), 2.36-2.33 (m, 2H), 1.96-1.92 (m, 1H), 1.74-1.64 (m, 4H). ${ }^{13} \mathrm{C}$ NMR (100 $\left.\mathrm{MHz}, \mathrm{CDCl}_{3}\right) \delta 213.4,140.0,137.4,130.9,128.8,127.5,127.4,126.9,126.1,58.1,46.4,40.3$, $34.8,28.4,21.5$.

General procedure for cleavage of ketones. A suspension of $\mathrm{KOH}(1.4 \mathrm{~g}, 25 \mathrm{mmol})$ in xylene $(50 \mathrm{~mL})$ was heated to reflux followed by dropwise addition of a solution of the ketone (2.5 mmol) in xylene $(1 \mathrm{~mL}$ ) over $10 \mathrm{~min}$ (for reactions where the GC yield was determined $150 \mathrm{mg}$ of nonane was also added as an internal standard). The reaction was stirred at reflux for an additional $1 \mathrm{~h}$. The mixture was cooled to room temperature and extracted with water $(3 \times 50$ $\mathrm{mL}$ ). The combined aqueous phases were carefully acidified with $6 \mathrm{M}$ hydrochloric acid to $\mathrm{pH} 2$ and then extracted with ethyl acetate $(3 \times 60 \mathrm{~mL})$. The combined organic layers were washed with brine, dried over $\mathrm{Na}_{2} \mathrm{SO}_{4}$ and concentrated in vacuo. The residue was purified by flash column chromatography (pentane/ethyl acetate $95 / 5 \rightarrow 80 / 20$ ) to afford the carboxylic acid. 
6-Phenylhexanoic acid (Table 2, entry 3): ${ }^{29}$ Isolated as a colorless oil in $78 \%$ yield $(374 \mathrm{mg}) .{ }^{1} \mathrm{H}$ $\operatorname{NMR}\left(400 \mathrm{MHz}, \mathrm{CDCl}_{3}\right) \delta 11.04(\mathrm{bs}, 1 \mathrm{H}), 7.26-7.30(\mathrm{~m}, 2 \mathrm{H}), 7.16-7.20(\mathrm{~m}, 3 \mathrm{H}), 2.62(\mathrm{t}, J=$ $7.7 \mathrm{~Hz}, 2 \mathrm{H}), 2.36(\mathrm{t}, J=7.5 \mathrm{~Hz}, 2 \mathrm{H}), 1.61-1.72(\mathrm{~m}, 4 \mathrm{H}), 1.36-1.44(\mathrm{~m}, 2 \mathrm{H}) .{ }^{13} \mathrm{C}$ NMR $(100$ $\left.\mathrm{MHz}, \mathrm{CDCl}_{3}\right) \delta 179.8,142.6,128.5,128.4,125.8,35.8,34.0,31.2,28.8,24.7$.

6-Phenylheptanoic acid (Table 2, entry 4): ${ }^{30}$ Isolated as a colorless oil in 40\% yield (206 mg). ${ }^{1} \mathrm{H}$ NMR (400 MHz, $\left.\mathrm{CDCl}_{3}\right) \delta 11.57(\mathrm{bs}, 1 \mathrm{H}), 7.52(\mathrm{t}, J=7.5 \mathrm{~Hz}, 2 \mathrm{H}), 7.27-7.24(\mathrm{~m}, 3 \mathrm{H})$, $2.79-2.74(\mathrm{~m}, 1 \mathrm{H}), 2.38(\mathrm{t}, J=7.6 \mathrm{~Hz}, 2 \mathrm{H}), 1.75-1.63(\mathrm{~m}, 4 \mathrm{H}), 1.38-1.19(\mathrm{~m}, 5 \mathrm{H}) .{ }^{13} \mathrm{C} \mathrm{NMR}$ $\left(100 \mathrm{MHz}, \mathrm{CDCl}_{3}\right) \delta 180.5,147.6,128.5,127.1,126.0,39.9,38.1,34.1,27.3,24.8,22.5$. 6-Phenyloctanoic acid (Table 2, entry 5): Isolated as a colorless oil in $65 \%$ yield (374 mg). ${ }^{1} \mathrm{H}$ $\operatorname{NMR}\left(400 \mathrm{MHz}, \mathrm{CDCl}_{3}\right) \delta 10.66(\mathrm{bs}, 1 \mathrm{H}), 7.27(\mathrm{t}, J=7.6 \mathrm{~Hz}, 2 \mathrm{H}), 7.18(\mathrm{t}, J=7.5 \mathrm{~Hz}, 1 \mathrm{H})$, $7.13(\mathrm{~d}, J=7.5 \mathrm{~Hz}, 2 \mathrm{H}), 2.44-2.36(\mathrm{~m}, 1 \mathrm{H}), 2.30-2.26(\mathrm{~m}, 2 \mathrm{H}), 1.72-1.42(\mathrm{~m}, 6 \mathrm{H}), 1.29-1.13$ $(\mathrm{m}, 2 \mathrm{H}), 0.76(\mathrm{t}, J=7.4 \mathrm{~Hz}, 3 \mathrm{H}) .{ }^{13} \mathrm{C} \mathrm{NMR}\left(100 \mathrm{MHz}, \mathrm{CDCl}_{3}\right) \delta 180.2,145.7,128.4,127.8$, 126.0, 47.8, 36.2, 34.1, 29.9, 27.2, 24.9, 12.3. HRMS: $\mathrm{m} / z$ calcd for $\mathrm{C}_{14} \mathrm{H}_{20} \mathrm{O}_{2} \mathrm{Na} 243.1356[\mathrm{M}+$ $\mathrm{Na}^{+}$, found 243.1348 .

6,7-Diphenylheptanoic acid (Table 2, entry 6): Isolated as a yellowish solid in 76\% yield (534 mg). Mp: $77-80{ }^{\circ} \mathrm{C}$ (ethanol). ${ }^{1} \mathrm{H}$ NMR (400 MHz, $\left.\mathrm{CDCl}_{3}\right) \delta 10.94$ (bs, $\left.1 \mathrm{H}\right), 7.28-7.21(\mathrm{~m}$, 2H), 7.21-7.12 (m, 4H), $7.10(\mathrm{~d}, J=6.9 \mathrm{~Hz}, 2 \mathrm{H}), 7.01(\mathrm{~d}, J=7.0 \mathrm{~Hz}, 2 \mathrm{H}), 2.89-2.87(\mathrm{~m}, 2 \mathrm{H})$, 2.84-2.77 (m, 1H), 2.26-2.21 (m, 2H), 1.74-1.46 (m, 4H), 1.22-1.15 (m, 2H). ${ }^{13} \mathrm{C}$ NMR (100 $\left.\mathrm{MHz}, \mathrm{CDCl}_{3}\right) \delta 180.3,145.0,140.7,129.3,128.4,128.2,127.8,126.2,125.9,48.0,44.0,35.2$ 33.9, 27.1, 24.8. HRMS: $m / z$ calcd for $\mathrm{C}_{19} \mathrm{H}_{22} \mathrm{O}_{2} \mathrm{Na} 305.1512[\mathrm{M}+\mathrm{Na}]^{+}$, found 305.1512 . 3-(o-Tolyl)propanoic acid (Table 2, entry 7): ${ }^{31}$ Isolated as a colorless oil in $18 \%$ yield (74 mg). ${ }^{1} \mathrm{H}$ NMR (400 MHz, $\left.\mathrm{CDCl}_{3}\right) \delta 7.18-7.12(\mathrm{~m}, 4 \mathrm{H}), 2.98-2.94(\mathrm{~m}, 2 \mathrm{H}), 2.67-2.63(\mathrm{~m}, 2 \mathrm{H}), 2.33$ 
(s, 3H). ${ }^{13} \mathrm{C} \mathrm{NMR}\left(100 \mathrm{MHz}, \mathrm{CDCl}_{3}\right) \delta 178.8,138.3,136.1,130.5,128.5,126.6,126.3,34.4$, $28.1,19.4$

5-Phenylpentanoic acid (Table 2, entry 8): ${ }^{29}$ Isolated as a colorless oil in 64\% yield (285 mg). ${ }^{1} \mathrm{H}$ NMR (400 MHz, $\left.\mathrm{CDCl}_{3}\right) \delta 11.8(\mathrm{bs}, 1 \mathrm{H}), 7.30-7.26(\mathrm{~m}, 2 \mathrm{H}), 7.20-7.17(\mathrm{~m}, 3 \mathrm{H}), 2.66-2.62$ (m, 2H), 2.40-2.36 (m, 2H), 1.70-1.67 (m, 4H). $\left.{ }^{13} \mathrm{C} \mathrm{NMR} \mathrm{(100} \mathrm{MHz,} \mathrm{CDCl}_{3}\right) \delta 179.5,142.1$, $128.5,128.5,126.0,35.7,33.9,30.9,24.4$

2-(o-Tolyl)acetic acid (Table 2, entry 9): ${ }^{32}$ Isolated as a white solid in $90 \%$ yield $(338 \mathrm{mg}) .{ }^{1} \mathrm{H}$ NMR (400 MHz, $\left.\mathrm{CDCl}_{3}\right) \delta 7.21-7.17(\mathrm{~m}, 4 \mathrm{H}), 3.67(\mathrm{~s}, 3 \mathrm{H}), 2.33(\mathrm{~s}, 2 \mathrm{H}) .{ }^{13} \mathrm{C} \mathrm{NMR}(100 \mathrm{MHz}$, $\left.\mathrm{CDCl}_{3}\right) \delta 177.3,137.0,132.0,130.4,130.3,127.7,126.2,38.8,19.6$.

Computational Details. All calculations were performed in Jaguar ${ }^{33}$ by using the Maestro graphical interface. ${ }^{34}$ All the structures were optimized in the gas phase and the single-point solvation energy was calculated for the optimized structures by using a standard PoissonBoltzmann solver with suitable parameters for water or xylene as the solvent. Default dielectric constant and probe radius were used for solvation with water while for xylene the following parameters were employed: dielectric constant $\varepsilon=2.2$, probe radius $r=2.9 \AA$. Gibbs free energies were obtained from the vibrational-frequency calculations for the gas-phase geometries at $298 \mathrm{~K}$ and $311 \mathrm{~K}$ (for structures from Figure 5) or $411 \mathrm{~K}$ (for structures from Figure 6). All the transition states were characterized by the presence of one negative vibrational frequency. Graphical representation of the calculated structures was made in CYLview. ${ }^{35}$

\section{ACKNOWLEDGMENT}

We thank the Danish Council for Independent Research - Technology and Production Sciences for financial support (grant 09-066621). 
Supporting Information. Copies of ${ }^{1} \mathrm{H}$ and ${ }^{13} \mathrm{C}$ NMR spectra for the prepared compounds, kinetic data, derivation of equation 1 as well as energies and coordinates from the DFT calculations. This material is available free of charge via the Internet at http://pubs.acs.org.

\section{References}

1) Artamkina, G. A.; Beletskaya, I. P. Russ. Chem. Rev. 1987, 56, 983-1001.

2) (a) Guthrie, J. P.; Cossar, J. Can. J. Chem. 1990, 68, 1640-1642. (b) Zucco, C.; Lima, C. F.; Rezende, M. C.; Vianna, J. F.; Nome, F. J. Org. Chem. 1987, 52, 5356-5359. (c) Guthrie, J. P.; Cossar, J. Can. J. Chem. 1986, 64, 1250-1266.

3) Symons, E. A.; Clermont, M. J. J. Am. Chem. Soc. 1981, 103, 3127-3130.

4) (a) Rahil, J.; Pratt, R. F. J. Am. Chem. Soc. 1977, 99, 2661-2665. (b) Fedor, L. R.; Murty, B. S. R.; De, N. C. J. Am. Chem. Soc. 1975, 97, 4308-4312. (c) Pearson, R. G.; Mayerle, E. A. J. Am. Chem. Soc. 1951, 73, 926-930.

5) Hine, J.; Koser, G. F. J. Org. Chem. 1971, 36, 1348-1351.

6) (a) Stranberg, M.; Anselme, J.-P. J. Chem. Educ. 1990, 67, 616. (b) Danilov, S. J. Russ. Phys. Chem. Soc. 1917, 49, 282-288.

7) (a) Forbes, E. J.; Gregory, M. J. J. Chem. Soc. B 1968, 205-207. (b) Bunnett, J. F.; Miles, J. H.; Nahabedian, K. V. J. Am. Chem. Soc. 1961, 83, 2512-2516.

8) Calas, M.; Calas, B.; Giral, L. Bull. Soc. Chim. Fr. 1976, 857-861. 
9) (a) Artamkina, G. A.; Grinfel'd, A. A.; Beletskaya, I. P. Bull. Acad. Sci. USSR 1983, 32, 345-352. (b) Hausigk, D. Chem. Ber. 1971, 104, 2637-2639. (c) Davies, D. G.; Derenberg, M.; Hodge, P. J. Chem. Soc. C 1971, 455-460.

10) Pearson, R. G.; Dillon, R. L. J. Am. Chem. Soc. 1948, 70, 1933-1936.

11) Mehta, G.; Venkateswaran, R. V. Tetrahedron 2000, 56, 1399-1422.

12) For more recent examples, see: (a) Casas-Solvas, J. M.; Mooibroek, T. J.; Sandramurthy, S.; Howgego, J. D.; Davis, A. P. Synlett 2014, 2591-2594. (b) Ben-Haida, A.; Hodge, P. Org. Biomol. Chem. 2012, 10, 1754-1763. (c) Wang, Q.; Chen, C. Org. Lett. 2008, 10, 1223-1226. (d) Yamada, Y. M. A.; Uozumi, Y. Tetrahedron 2007, 63, 8492-8498. (e) Bello, A. M.; Kotra, L. P. Tetrahedron Lett. 2003, 44, 9271-9274. (f) Mehta, G.; Reddy, D. S. J. Chem. Soc., Perkin Trans. 1 2001, 1153-1161. (g) Zabjek, A.; Petric, A. Tetrahedron Lett. 1999, 40, 6077-6078. (h) Maslak, P.; Varadarajan, S.; Burkey, J. D. J. Org. Chem. 1999, 64, 8201-8209.

13) For recent examples, see: (a) Sarma, M. J.; Borah, A. J.; Rajbongshi, K. K.; Phukan, P. Tetrahedron Lett. 2015, 56, 7008-7011. (b) Braun, I.; Rudroff, F.; Mihovilovic, M. D.; Bach, T. Synthesis 2007, 3896-3906. (c) Ishihara, K.; Yano, T. Org. Lett. 2004, 6, 1983-1986.

14) Li, J. J. Name Reactions: A Collection of Detailed Mechanisms and Synthetic Applications; 5. Ed.; Springer, 2014, p. 299.

15) Santilli, C.; Makarov, I. S.; Fristrup, P.; Madsen, R. J. Org. Chem. 2016, 81, 9931-9938.

16) The release of formate from aldehydes is also an unusual enzymatic reaction catalyzed by cyanobacterial aldehyde-deformylating oxygenase under aerobic conditions, see: Shokri, A.; Que, L, Jr. J. Am. Chem. Soc. 2015, 137, 7686-7691. 
17) The reason could also be the formation of hydrogen bonded species as observed in the Mitsunobu esterification reaction where the addition of more nucleophile leads to slower reactions, see: Hughes, D. L.; Reamer, R. A.; Bergan, J. J.; Grabowski, E. J. J. J. Am. Chem. Soc. 1988, 110, 6487-6491.

18) For other Hammett studies employing competition kinetics, see: (a) Fristrup, P.; Tursky, M.; Madsen, R. Org. Biomol. Chem. 2012, 10, 2569-2577. (b) Fristrup, P.; Kreis, M.; Palmelund, A.; Norrby, P.-O.; Madsen, R. J. Am. Chem. Soc. 2008, 130, 5206-5215. (c) Dam, J. H.; Fristrup, P.; Madsen, R. J. Org. Chem. 2008, 73, 3228-3235. (d) Keinicke, L.; Fristrup, P.; Norrby, P.-O.; Madsen, R. J. Am. Chem. Soc. 2005, 127, 15757-15761.

19) The GC yields of the para-substituted toluenes ( $\mathrm{X}=\mathrm{OMe}, \mathrm{Et}, \mathrm{Cl}$ and $\mathrm{F}$ ) varied between $42 \%$ and $65 \%$.

20) See the Supporting Information for the derivation of the equation.

21) For our recent computational studies on other carbonyl addition reactions, see: (a) reference 15. (b) Makarov, I. S.; Fristrup, P.; Madsen, R. Chem. Eur. J. 2012, 18, $15683-15692$.

22) Bryantsev, V. S.; Diallo, M. S.; van Duin, A. C. T.; Goddard, W. A., III J. Chem. Theory Comput. 2009, 5, 1016-1026.

23) He, C.; Guo, S.; Huang, L.; Lei, A. J. Am. Chem. Soc. 2010, 132, 8273-8275.

24) Sifton, W.; Stothers, J. B.; Thomas, S. E. Can. J. Chem. 1992, 70, 1274-1280.

25) Reichle, M. A.; Breit, B. Angew. Chem. Int. Ed. 2012, 51, 5730-5734.

26) Haffemayer, B.; Gulias, M.; Gaunt, M. J. Chem. Sci. 2011, 2, 312-315.

27) Nedenskov, P.; Taub, W.; Ginsburg, D. Acta Chem. Scand. 1958, 12, 1405-1410.

28) Kano, T.; Hayashi, Y.; Maruoka, K. J. Am. Chem. Soc. 2013, 135, 7134-7137. 
29) Owen, C. P.; Shahid, I.; Olusanjo, M. S.; Patel, C. H.; Dhanani, S.; Ahmed, S. J. Steroid Biochem. Mol. Biol. 2008, 111, 117-127.

30) Weix, D. J.; Dreher, S. D.; Katz, T. J. J. Am. Chem. Soc. 2000, 122, 10027-10032.

31) Lim, M.; De Castro, K. A.; Oh, S.; Lee, K.; Chang, Y.-W.; Kim, H.; Rhee, H. Appl. Organomet. Chem. 2011, 25, 1-8.

32) Hassner, A.; Ruse, M.; Gottlieb, H. E.; Cojocaru, M. J. Chem. Soc., Perkin Trans. 1 1988, $733-737$.

33) Jaguar, version 9.0, Schrodinger, Inc., New York, NY, 2015.

34) Bochevarov, A. D.; Harder, E.; Hughes, T. F.; Greenwood, J. R.; Braden, D. A.; Philipp, D. M.; Rinaldo, D.; Halls, M. D.; Zhang, J.; R. Friesner, A. Int. J. Quantum Chem. 2013, $113,2110-2142$.

35) Legault, C.Y. CYLview, version 1.0b, Université de Sherbrooke, 2009. 